\title{
DEATH IN LITERATURE
}

\section{DIFFERENT APPROACHES, FROM SIMPLICITY TO OBSCURITY}

\author{
JOHN SKELTON
}

This study looks briefly at a range of ways in which writers have approached the concept of death, from expressions of personal grief, through to the ways in which attitudes to death represented in a culture are also picked up and used by writers from the culture concerned. Writers considered are mostly (but not all) from the English and Spanish language traditions, and in particular Seamus Heaney, Thomas Hardy, Miguel de Cervantes and Federico García Lorca. The point is made that not all writing about death is centred on death as a source of personal grief, though a great deal is. Also considered is the way in which some writing about death is transparent, and in a sense overtly simple, while other writing is less so, and may even seem obscure.

Keywords: death, literature, medical humanities, grief, approaches to dying.

Some years ago, I contributed a chapter to The study of dying: From autonomy to transformation (Skelton, 2009) a book which brought together individuals from medicine, palliative care, philosophy and the arts. «The aim of this volume», said the editor, «is to dare us to pause and think again, and to reexamine our common fate more carefully, more thoughtfully, even more hopefully» (Kellehear, 2009, p. 13).

Certainly, one of the central points I sought to make was that great writers make themes their own, and make us look again. «Dying» in literature is a complex
"THERE ARE GREAT DEATH SCENES IN LITERATURE, AND THERE ARE BEAUTIFUL AND MOVING STATEMENTS ABOUT THE DEATH OF LOVED ONES" death is rendered simply, then at Don Quixote, as an example of how death as a theme can be employed ambiguously, and then at death described at the very edge of comprehension. thing, and asking what writers

make of it may even sometimes be,

I suggested, a dangerously vacuous question, a little like asking, «What do writers write about?». After all, John Keats's great odes -which I discussed in a little detail (Skelton, 2009)- were written by a man aware of the probable imminence of his own death, about a desire for permanence when the human experience is of transience. But one can perfectly well read and love Ode to Autumn without knowing the poet will die soon, and in that sense it is not, or not just, a contemplation of dying.

That volume was specifically about dying, not death itself; in this short study I pick up on some of the points I made then, and rework them looking at death. I have also tried a little to look at literature where

\section{SIMPLICITY}

I should like to begin with the Nobel Prize winning poet Seamus Heaney.

Heaney wrote a series of sonnets following the death of his mother, Margaret. The best known of these poems, collectively known as «Clearances» (Heaney, 1987), is this:

When all the others were away at Mass I was all hers as we peeled potatoes.

They broke the silence, let fall one by one Like solder weeping off the soldering iron: Cold comforts set between us, things to share Gleaming in a bucket of clean water. And again let fall. Little pleasant splashes From each other's work would bring us to our senses.

So while the parish priest at her bedside Went hammer and tongs at the prayers for the dying And some were responding and some crying I remembered her head bent towards my head, Her breath in mine, our fluent dipping knives Never closer the whole rest of our lives. 


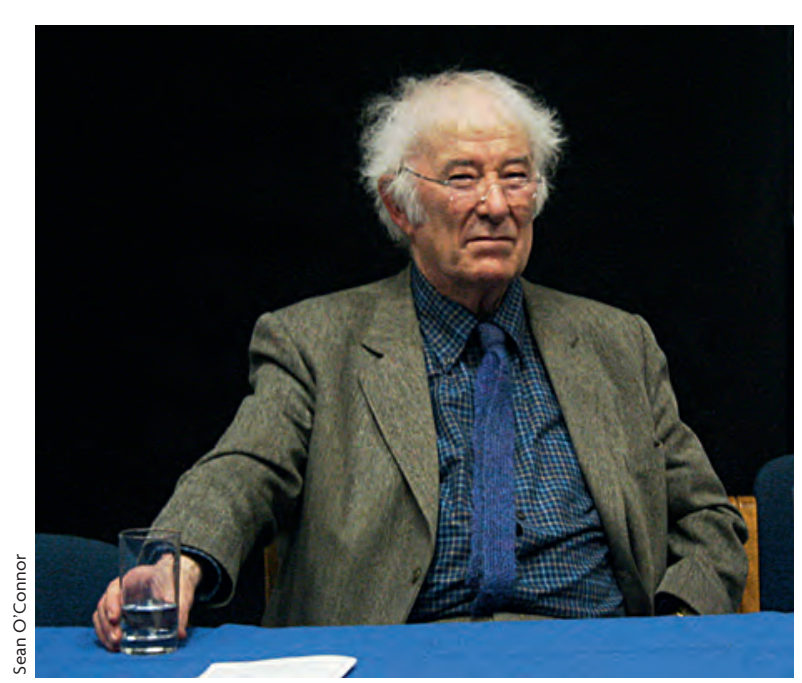

Nobel Prize winner Seamus Heaney wrote the poem "Clearances» in memory of his deceased mother. Above, a photo of the poet.

The poem is simple, in the sense that it is quite transparent - the picture of the young boy sharing a precious moment alone with his mother (Heaney was the eldest of nine siblings, one of whom died young) is something most of us can understand and, if we are lucky, remember. The art of the poem - the reason it is so wonderfully heartbreaking - is in the small details of a master craftsman at work. It is a long way from being an entirely regular sonnet. The rhyme scheme for the sextet - the last six lines - is that of a Shakespearean sonnet, if you allow «bedside» and «head» to count as rhymes; but the rhymes, such as they are, in the octet follow no pattern. This keeps the poem aloft, not quite allowing the reader to stop as a rhyme does, but inviting one on. Then there are the frequent alliterations, drawing on the Anglo-Saxon tradition of which Heaney was an admirer: notice in particular the lovely recurrence of $/ p l /$ in «pleasant splashes». And there is the final ambiguous «Never closer...», which leaves open the question of how close they were, and whether the poet regrets not being closer. And behind all of this, there is the sense of quiet rebellion, the mother and son not doing the conventional thing and going to Mass.

Behind the poem, in fact, is this, an answer Heaney gave in an interview (O'Driscoll, 2008):

I could see that religion was a powerful compensation for [my mother]. There she was, doomed to biology, a regime without birth control, nothing but parturition and potato peeling....

And yet, to understand the full range of Heaney's craft, here is another brief extract from «Clearances», again a picture of an activity shared with his mother:
The cool that came off sheets just off the line Made me think the damp must still be in them But when I took my corners of the linen And pulled against her, first straight down the hem And then diagonally, then flapped and shook The fabric like a sail in a cross-wind,

They made a dried-out undulating thwack.

Seven lines, one sentence, about folding a sheet, ending with that satisfying «thwack»: and if one is listening for the octet/sextet pattern, this sudden closure a line early is doubly satisfying. It is, in its own quiet way, perfect.

Let me turn now briefly to another poem about bereavement. Thomas Hardy's wife Emma died in 1912. He embarked upon a series of poems on his loss, of which After a journey is the best known. It was written in Cornwall in 1913, in a setting he and Emma had visited forty years previously (Hardy, 1994; The Thomas Hardy Society, n. d.). It begins:

Hereto I come to view a voiceless ghost Whither oh whither will its whim now draw me Up the cliff, down till I'm lonely, lost

And the unseen waters' ejaculations awe me Where you will next be there's no knowing, Facing round about me everywhere,

With your nut-coloured hair,

And gray eyes, and rose-flush coming and going

Despite one or two unusual words, the only difficult thing about this poem is the rhythm, which often falters in mimickry of the elderly and uncertain Hardy. It needs therefore to be read aloud, and in such a way that it continues to sound like poetry.

Emma's «ghost» is described as entirely «real», and - as any healthcare professional who deals

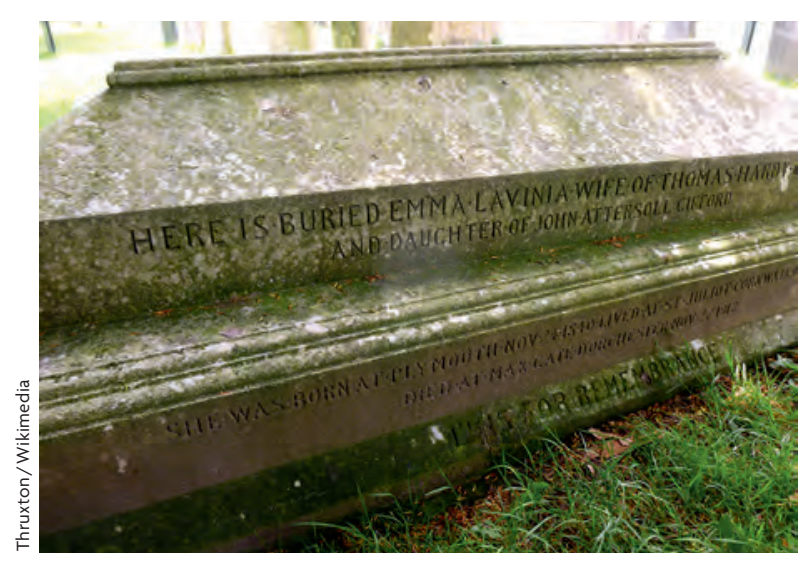

Emma, the first wife of author Thomas Hardy, died in 1912. The poet embarked on the composition of a series of poems about his loss, the most famous of which is After a journey. In the photo, the tomb of Emma Gifford in Dorset (England). 
as El ingenioso hidalgo don Quijote de la Mancha

(Cervantes, 1999; 2004).

The death of don Quixote is one of the great setpieces of western literature. It begins:

Como las cosas humanas no sean eternas, yendo siempre en declinación de sus principios hasta llegar a su último fin, especialmente las vidas de los hombres, y como la de don Quijote no tuviese privilegio del cielo para detener el curso de la suya, llegó su fin y acabamiento cuando él menos lo pensaba [...]. ${ }^{1}$

However, despite that como ("as" in english) at the start, there is no sensible statement about cause and effect. It makes no sense at all to say that don Quixote's end was unexpected because nothing lasts forever. It is a Cervantes trick to turn an apparent infelicity of style into a subconscious reminder of how slippery the ground is beneath one's feet. And what does it mean to say «all tends downwards», especially life? Compared to what, exactly, does life tend more steeply or surely down?

Well, Cervantes plunges happily on (some readers have found his style merely clumsy, but if so, it is built into the act), with that innocent air of not being quite in control of his words:

[...] porque o ya fuese de la melancolía que le causaba el verse vencido o ya por la disposición del cielo, que así lo ordenaba, se le arraigó una calentura que le tuvo seis días en la cama $[\ldots]^{2}$

So, he introduces a choice - an ambiguity of his own: I don't really know, he says, if it was defeat that made him sad or heaven's will.

Don Quixote sleeps, but:

Despertó al cabo del tiempo dicho y, dando una gran voz, dijo:

- ¡Bendito sea el poderoso Dios, que tanto bien me ha hecho! En fin, sus misericordias no tienen límite, ni las abrevian ni impiden los pecados de los hombres. ${ }^{3}$

\footnotetext{
1 As nothing that is man's can last for ever, but all tends downwards from its beginning to its end, and above all man's life, and as Don Quixote's enjoyed no special dispensation from heaven to stay its course, its end and close came when he least looked for it [...].

${ }^{2}$ For - whether it was of the dejection the thought of his defeat produced, or of heaven's will that so ordered it - a fever settled upon him and kept him in his bed for six days [...].

${ }^{3}$ At the end of that time he woke up, and in a loud voice exclaimed, «Blessed be Almighty God, who has shown me such goodness. In truth his mercies are boundless, and the sins of men can neither limit nor keep them back!».
}

It's oddly similar at this instant to the death of Ivan Ilyich, main character of Lev Tolstoy's homonymous novel, who also wakes up following an ambiguous revelation of a sort (Skelton, 2009). But, of course, the others gathered round think this is just some new form of madness.

In the final paragraph, and final peroration, Cervantes begins: «For me alone was don Quixote born, and I for him; it was his to act, mine to write». So, at this stage, the book about don Quixote is real. The man don Quixote is not real, and never has been. The man Alonso who once thought he was don Quixote recognises he was wrong. But Alonso Quijano is dead, and actually don Quixote never existed. Yet at this moment ( $\ll$ it was his to act and mine to write») Cervantes seems to offer Quixote some kind of life outside the book. This too is death being used as an exploration of what is real.

\section{OBSCURITY}

Cervantes offers an illusion of simplicity. Others do not. But to

be «obscure» is no bad thing.

It is worth remembering Thomas S. Eliot's point - there are various version of the idea in Eliot's writings, but this is particularly clear, from a letter of 1930, to G. W. S. Curtis, June 17th.

[...] As for obscurity, I like to think that there is a good and a bad kind: the bad, which merely puzzles or leads astray; the good, that which is the obscurity of any flower: something simple and to be simply enjoyed, but merely incomprehensible as anything living is incomprehensible. [...] «Understanding» poetry seems to me largely to consist of coming to see that it is not necessary to «understand».

(Eliot and Haffenden, 2014)

Some literature offers a conundrum which is resolved (the essence of a whodunnit), but great literature does not. Indeed, great literature gets away with being pretty well incomprehensible, sometimes, precisely because the reader has faith that -if you just let the aesthetic experience happen- a set of meanings will eventually form itself for you.

In this sense, the poet Federico Garcia Lorca is of obvious relevance. His poems are vivid, but constantly hover on the very edge of sense: and it has been acknowledged, certainly since Pedro Salinas made the point (Salinas, 1955), that: «el reino poético 
Death is at the heart of the poetry, but its binding force is the driving, subtle rhythms. This is what most obviously rescues the poems when they seem about to topple into meaninglessness - a point nowhere more simply illustrated than in his most famous line of all, the opening of Romance Sonámbulo (García Lorca, 2011). «Verde que te quiero verde», whose English translation, «Green how I want you [or love you] green» is simply empty because the rhythm is uninteresting. On the contrary, in a reading of his poems he spoke of:

Una gran sensación de anécdota, un agudo ambiente dramático y nadie sabe lo que pasa ni aun yo, porque el misterio poético es también misterio para el poeta que lo comunica, pero que muchas veces lo ignora. ${ }^{7}$

(García Lorca, 2015, vol. II, p. 84)

Everyone is a ghost, or a dream, or about to become one.

The Romance de la luna, luna (García Lorca, 2015) is a statement of just this. It appears to be the story of a young gipsy boy, in the forge, left on his own one night. He is tempted in some sense by the moon, personified as a woman, and as a dancer, and also death. The child tells the moon to flee before the gypsies get back («Huye luna, luna, luna»), but the moon tells him that when the gypsies return they will find him «con los ojillos cerrados», with his eyes shut (and therefore dead). This is what happens, and the poem closes with what is a lament over the child's body: «Dentro de la fragua lloran,/dando gritos, los gitanos./El aire la vela, vela./El aire la está velando» ${ }^{8}$. «El aire la vela...» can be translated «the air watches over him», but una vela is also both a candle and a sail, so there are overtones of the flickering light and the idea of the child and the moon sailing through the heavens.

Death, then, written about with such a sense of mystery, becomes a much more complicated thing.

\section{OTHER CULTURAL APPROACHES}

Finally, death in literature reflects attitudes to death in the culture it springs from.

This is perhaps most evident in the Japanese tradition, and that lets us draw attention to the

\footnotetext{
${ }^{7}$ «A great sensation of anecdote, a sharp dramatic atmosphere, and noone knows what's happening, not even me, because the mystery is also a mystery for the poet who communicates it, but who often does not know what it is.» Translated by the author.

8 «Within the forge the gypsies cry and shout. The air keeps watch, keeps watch. The air is keeping watch.»

Translated by the author.
}

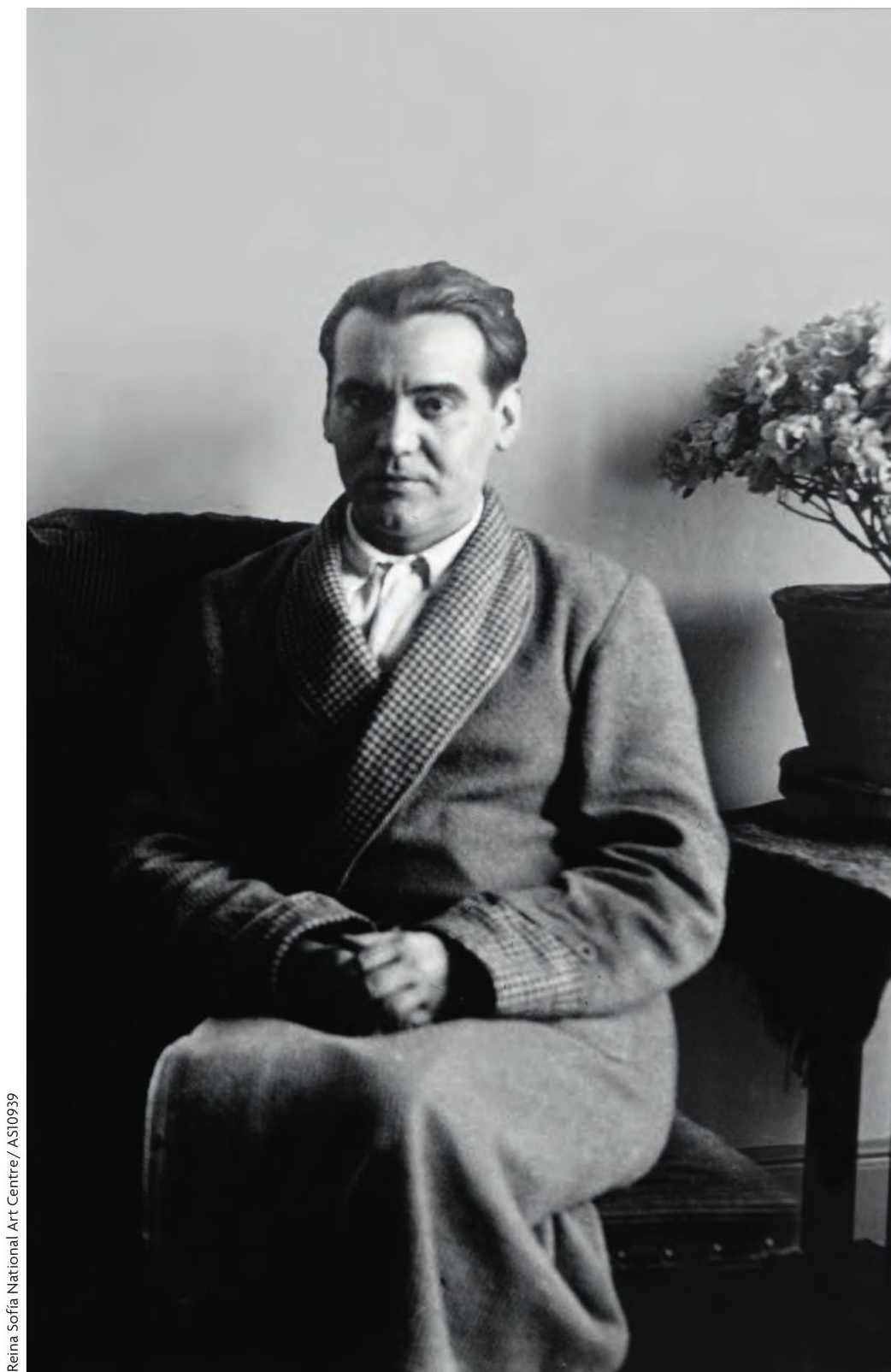

Federico García Lorca writes about death with such a sense of mystery that it makes the concept much more complex. The picture shows the poet portrayed in 1930 by Alfonso Sánchez Portela. The photograph is part of the "Alfonso Sánchez Portela" collection currently housed in the Reina Sofía National Art Centre (Madrid, Spain).

«DEATH, THEN, WRITTEN ABOUT

WITH SUCH A SENSE OF MYSTERY

BY LORCA, BECOMES A MUCH MORE COMPLICATED THING» 


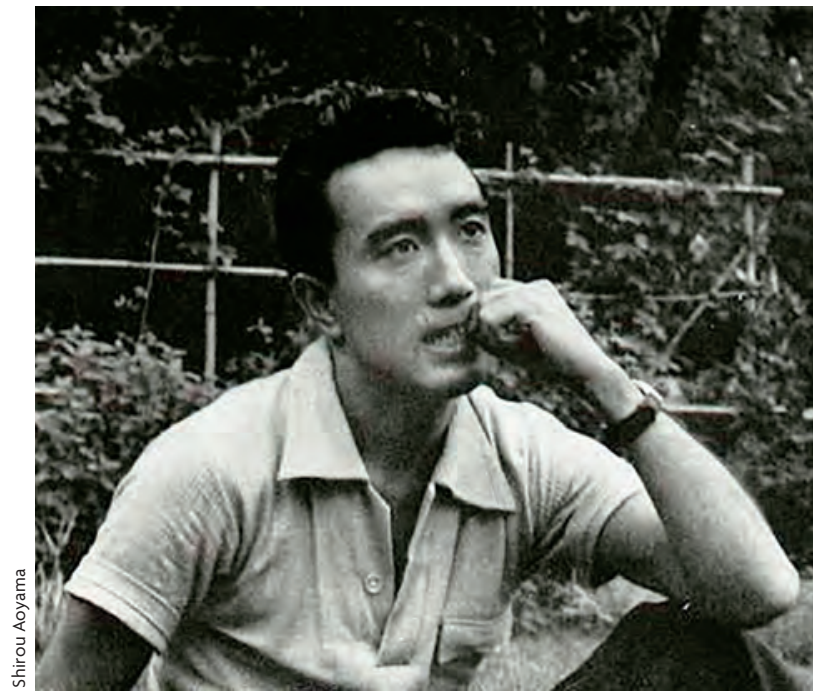

Yukio Mishima, the Japanese novelist who amongst his other themes sought to be the spokesman of a kind of cultural approach to death, committed ritual suicide in an attempt to remind Japan of what he perceived as one of its glorious traditions. Above, the writer in 1956

\section{"THE JAPANESE TRADITION OF WRITING A 'JISEI', OR DEATH POEM, WHEN DEATH -PERHAPS SUICIDE- IS IMMINENT"}

universality of some of the strands I have briefly teased out. A central theme of Japanese writing has always been a sense of pathos (the ubiquitous phrase mono no aware is usually translated as "the pathos of things"). It found its greatest expression in The Tale of Genji, a tenth-century masterpiece written by Murasaki Shikibu at the height of the Heian age (Shikibu, 2003).

In part, mono no aware reflects a Buddhist view, as does the Japanese tradition of writing a jisei, or death poem, when death - perhaps suicide - is imminent. Yukio Mishima, the Japanese novelist who amongst his other themes sought to be the spokesman of a kind of cultural approach to death, notoriously committed ritual suicide in an attempt to recall Japan to what he perceived as one of its glorious traditions. His death poem was: «A small night storm blows/Saying "falling is the essence of a flower" / Preceding those who hesitate» (Sensitivity to things, n.d.).

Frankly, it seems a miserable end to a major talent. But the jise $i$ also demonstrate both the manner in which death in literature is treated as a public event, from poems written In memoriam, like, for instance, Tennyson's outpouring of grief at the death of his friend Arthur Hallam (Tennyson, 2017); and the desire to die well, the ars morendi (Skelton, 2009).

\section{CONCLUSION}

There are great death scenes in literature, and there are beautiful and moving statements about the death of loved ones, from the subtle lament by Catullus on the death of his brother (Catullus, n. d.), to Dr Johnson's lovely poem on his friend Dr Levet (Johnson, 1986). At the other end of the scale is the existential indifference shown by the narrator of Camus' The outsider: «My mother died today. Or maybe yesterday. I don't know» (Camus, 2012). A great deal of death in literature, then, describes our responses to the death of individuals. But death is so fully at the heart of life that it is fully at the heart of poetry. To understand death better in the end is to understand life better: and to understand death in literature is to understand how literature works to show it and contextualise it. ()

\section{REFERENCES}

Camus, A. (2012). The outsider. London: Penguin.

Catullus. (n. d.). Catullus 65. Retrieved 22 July 2017, from https:// en.wikisource.org/wiki/Translation:Catullus 65

Cervantes, M. (1999). El ingenioso hidalgo Don Quijote de la Mancha. Retrieved July 22, 2017, from http://www.gutenberg.org/ files/2000/2000-h/2000-h.htm\#2_lxxiv

Cervantes, M. (2004). Don Quixote. Retrieved July 22, 2017, from http:// www.gutenberg.org/cache/epub/996/pg996.html

Eliot, V., \& Haffenden, J. (Eds). (2014). The letters of T. S. Eliot, vol 5: 1930-31. London: Faber.

García Lorca, F. (1974). Teoría y juego del duende. Romance sonámbulo. In A. del Hoyo, (Ed.), Obras completas vol. 1 (pp. 1067-1082, p. 1085). Madrid: Aguilar.

García Lorca, F. (2015). Romancero gitano. Poema del cante jondo. Poesía completa II. Barcelona: DeBolsillo.

Hardy, T. (1994). After a journey. In M. Irwin (Ed.), The collected poems of Thomas Hardy. Ware: Wordsworth Poetry Library.

Heaney, S. (1987). Clearances. In S. Heaney, The Haw lantern. London: Faber and Faber.

Johnson, S. (1986). On the death of Dr. Robert Levet. In J. D. Fleeman (Ed.), Samuel Johnson: The complete English poems. Yale: Yale University Press.

Kellehear, A. (Ed.). (2009). The study of dying: From autonomy to transformation. Cambridge. University Press.

O'Driscoll, D. (2008). Growing into poetry. In D. O'Driscoll (Ed.), Interviews with Seamus Heaney (p. 39). London: Faber and Faber.

Salinas, P. (1955). Lorca and the poetry of death. Carleton Drama Review, 1(2), 14-21.

Sensitivity to things. (n.d.). The poetry of death. Retrieved from http:// sensitivitytothings.com/2008/03/22/poetry-of-death

Shikibu, M. (2003). The tale of Genji. London: Penguin.

Skelton, J. R. (2009). Dying in Western literature. In A. Kellehear (Ed.), The study of dying: From autonomy to transformation (pp. 188-210). Cambridge: Cambridge University Press.

Tennyson, A. (2017). In Memoriam A. H. H. Victoria: Leopold Classic Library.

The Thomas Hardy Society (n. d.). After a journey. Retrieved July 25, 2017, from http://www.hardysociety.org/poems/all.php

John Skelton. Professor of Clinical Communication and Head of Education Quality at the College of Medical and Dental Sciences at the University of Birmingham (United Kingdom). He has published more than one hundred academic papers on aspects of clinical communication, medical education, medical humanities and applied linguistics. He is the author of Language and clinical communication: This bright Babylon and Role-play and clinical communication (both in Radcliffe Medical Press, 2008), and is one of the very few non-Clinicians to be awarded Honorary Fellowship of the UK Royal College of General Practitioners. 